\title{
Responsabilidade Individual e Ação Revolucionária: direito e moral em Lukács anterior a sua obra História e Consciência de Classe
}

\author{
Individual Responsability and Revolutionary Action: Law and moral in Lukács \\ before his work History and Class Consciousness
}

Vitor Bartoletti Sartori ${ }^{1}$

${ }^{1}$ Universidade Federal de Minas Gerais, Belo Horizonte, MG, Brasil

\begin{abstract}
Resumo: Neste artigo, pretende-se tratar do modo peculiar segundo o qual Lukács, em seus escritos anteriores à obra História e consciência de classe, trata da moral e do Direito. A crítica à eticidade hegeliana leva o autor húngaro a uma ênfase bastante grande na ação e na responsabilidade individuais na mesma medida em que haveria, de um lado, um abismo entre a ação moral e a revolução e, de outro, uma unidade imediata entre ambas. A partir disso, por meio daquilo que o filósofo brasileiro José Chasin chamou de análise imanente, será possível chegar à relação existente entre o direito e a moralidade no momento da obra lukacsiana, aquele de 1919.
\end{abstract}

Palavras-chave: Lukács. Moral. Direito. Revolução. Pecado.
Abstract: We intend to deal with the peculiar way in which Lukacs, in his writings which would result in the essential of History and class consciousness, deals with Morality and Law. The criticism of Hegelian ethics leads the Hungarian author to a rather great emphasis on individual action and responsibility to the extent that there would be, on the one hand, an abyss between moral action and revolution, on the other, an immediate unity between the two. With what the brazilian philosopher José Chasin called immanent analysis we will show how morality and Law relate themselves at Lukács'work of 1919.

Keywords: Lukács. Moral. Law. Revolution. Sin.

Recebido em: 31/05/2019

Revisado em: 16/03/2020

Aprovado em: 20/03/2020 


\section{Introdução}

O caminho de György Lukács em direção ao marxismo é, segundo o próprio autor, bastante tortuoso (LUKÁCS, 2010). Aqui, a partir daquilo que o filósofo brasileiro José Chasin chamou de análise imanente ${ }^{1}$, procura-se explicitar os meandros desse percurso no que diz respeito ao Direito e à moral, temas que estarão presentes durante toda a produção do marxista húngaro (SARTORI, 2015). Ao abordar os escritos imediatamente anteriores à sua obra mais famosa, História e consciência de classe, de 1923, pretende-se demonstrar a centralidade que tem o debate moral nesse período específico do autor húngaro. Os textos que têm como centro Tática e ética, de 1919, mesmo que sejam fortemente marcados pelo impacto da Primeira Guerra Mundial, da Revolução Russa e da entrada do marxista húngaro no Partido Comunista (OLDRINI, 2017), trazem consigo uma concepção fortemente inspirada em Hegel e embebida da questão da moralidade (algo que, como será apontado, não é comum na filosofia inspirada no autor da Fenomenologia do espírito), tendo-se uma contraposição muito marcante, de um lado, entre a moral e a ética e, de outro, a coerção jurídica e a institucionalidade. Ou seja, aquilo que fora tratado por Lenin em Quê fazer? (certa centralidade do partido político) e que, em meio à Revolução alemã de 1918-1919, é retomado de modo mais desenvolvido em Esquerdismo doença infantil do comunis$m o$, texto em que Lenin ataca vigorosamente Tática e ética, e passa longe de constituir a principal preocupação de Lukács. Neste artigo, procura-se, então, demostrar as implicações práticas e teóricas disso.

Assim, os textos que serão tratados aqui encontram-se no início da produção marxista do autor húngaro. Portanto, antes de História e cons-

\footnotetext{
${ }^{1}$ Como aponta José Chasin (2009, p. 26): “[...] tal análise, no melhor da tradição reflexiva, encara o texto - a formação ideal - em sua consistência autosignificativa, aí compreendida toda a grade de vetores que o conformam, tanto positivos como negativos: o conjunto de suas afirmações, conexões e suficiências, como as eventuais lacunas e incongruências que o perfaçam. Configuração esta que em si é autônoma em relação aos modos pelos quais é encarada, de frente ou por vieses, iluminada ou obscurecida no movimento de produção do para-nós que é elaborado pelo investigador, já que, no extremo e por absurdo, mesmo se todo o observador fosse incapaz de entender o sentido das coisas e dos textos, os nexos ou significados destes não deixariam, por isso, de existir [...]".
} 
ciência de classe, texto que adere à tese leniniana da vanguarda revolucionária de modo sui generis (SARTORI, 2018a). Ao mesmo tempo, tais textos trazem temáticas que serão essenciais - entre elas, o locus da ética na atividade humana (TERTULIAN, 2016) - às principais obras de maturidade de Lukács, a Estética e a Ontologia do ser social. Pretende-se, ainda, demonstrar aqui como as questões do Direito e da moral são expressas nesses textos marxistas iniciais lukácsianos, que são, ao mesmo tempo, marcados pela esperança e pelo trauma de uma revolução como a russa. Ou seja, se é correto o que se diz, é bastante importante que se analise a questão que aqui será proposta. Isso se dá porque, se é verdade que Lukács é um dos maiores marxistas do século XX (MÉSZÁROS, 2002; 1972), seus rumos podem ser exemplares no que diz respeito aos pontos altos e às vicissitudes daquilo que Eric Hobsbawm chamou de "era dos extremos" (HOBSBAWM, 1994) O século XX é marcado pela Revolução Russa e por seus impactos. Assim, pode ser muito importante compreender um dos maiores expoentes do marxismo para que se entenda também as origens do nosso tempo.

Claro, a estatura teórica de Lukács (TERTULIAN, 2016), bem como o fato de ainda não existirem trabalhos no Brasil sobre o tema (e, até onde se sabe, com a mesma ênfase, eles também são inexistentes no exterior), justifica a abordagem do que aqui será anlisado. Só para que se possa dar um exemplo, o interessante livro chamado $O$ Direito no jovem Lukács, de Silvio Almeida (2006), trata exclusivamente de História e consciência de classe; assim, parece mais do que justificado analisar os escritos mais "juvenis" do autor húngaro. Justamente a partir da reformulação lukacsiana de alguns textos de 1919 (que aqui serão analisados na medida em que passam pelo Direito e pela moral) que surge o conjunto de ensaios que compõem a obra lukacsiana de 1923.

\section{Filosofia da História, Economia e Dignidade Humana}

A primeira vez que a temática política aparece como central na obra de Lukács é justamente em 1919. Antes disso, claro, a questão aparece. No entanto, o foco do marxista húngaro, via de regra, encontrava-se em 
preocupações estéticas. O socialismo, a revolução e a posição dos marxistas diante da história surgem com vigor marcante nos textos que aqui serão analisados. Veja-se:

O fim último do socialismo é utópico no sentido de que ultrapassa os marcos econômicos, legais e sociais da sociedade atual, e só pode ser realizado através da destruição desta sociedade; no entanto, não é utópico na medida em que o caminho para este fim último implica em uma realização de ideias que se encontram vacilantes, além dos limites da sociedade ou acima desta. A teoria marxista da luta de classes que, neste ponto, segue inescrupulosamente a obra conceitual hegeliana converte o objeto transcendente em imanente: a luta de classes é o objeto e, ao mesmo tempo, sua realização. Esse processo não é um meio cujo fim e o parâmetro haveria de se medir de acordo com o parâmetro de um fim que o excede; antes, representa uma nova manifestação da sociedade utópica, passo a passo, salto a salto, de acordo com a lógica da história. Isso significa uma imersão na realidade atual. Esse 'meio' não é alheio ao fim (como ocorria na realização da ideologia burguesa), mas uma aproximação do fim a sua autorrealização. Isso significa que entre os meios táticos e o fim último há transições conceitualmente indetermináveis; nunca há como saber de antemão que peso tático terá que tornar realidade já o seu próprio fim. Com isso, chegamos ao parâmetro decisivo da tática socialista: a filosofia da história. (LUKÁCS, 2005, p. 29)

Lukács será em sua obra madura um vigoroso crítico da utopia (TERTULIAN, 2016). Aqui, no entanto, ele afirma algo distinto, que o "fim último do socialismo é utópico", trazendo uma posição contra a qual se insurgirá de modo marcante posteriormente.

Ao mesmo tempo em que o marxista húngaro traz a noção de utopia - o "fim último do socialismo" ultrapassaria o existente, sendo realizável somente a partir da "destruição desta sociedade" -, ele procura escapar do idealismo. Para tanto, ele afirma que, mesmo que se tenha uma "realização de ideias que se encontram vacilantes", há certa conversão daquilo que é transcendente em imanente. E, nesse ponto, Lukács remete a Hegel 
explicitament ${ }^{2}$. A correlação dialética entre realização e objeto, por sua vez, apareceria na luta de classes. A questão é essencial.

A manifestação mesma da nova sociedade já estaria presente na luta de classes da classe trabalhadora. A antinomia entre meio e fim (tema central à tematização lukacsiana sobre as "antinomias do pensamento burguês”, em História e consciência de classe) estaria, até certo ponto, resolvida, por assim dizer, em ato. A medida colocada à luta de classes não seria transcendente, portanto. A imanência dessa medida, o parâmetro da própria atividade da classe trabalhadora, não estaria em "um fim que o excede". A questão ganha destaque justamente ao passo que existiria na luta da classe trabalhadora algo que "representa uma nova manifestação de sociedade utópica". E, nesse sentido, a utopia socialista, de certo modo, seria uma realidade que se explicitaria "passo a passo, salto a salto, de acordo com a lógica da história". Aquilo que Lukács enxerga na luta de classes da classe trabalhadora, pode-se dizer, é nada menos que o socialismo se desentranhando em meio à luta contra a sociedade capitalista. Isso traz uma posição que pode ser relacionada ao processo pelo qual, após a Revolução Russa, revoluções - depois derrotadas - apareceram na Alemanha, na Hungria (com a participação do próprio autor de Tática e ética) e em outros países.

Ou seja, a noção de utopia do Lukács de 1919 é essencialmente imanente, por mais que essa imanência apareça de modo sui generis na obra do autor, com referências teológicas, inclusive.

Percebe-se, assim, que a luta de classes aparece como a realização de uma utopia. A ausência de contradição entre meio e fim faz com que essa luta seja a expressão de uma nova sociedade.

Esse ponto precisa ser esclarecido. A manifestação empírica da luta de classes, certamente, não é nada parecida com uma utopia (no sentido utilizado pelo autor húngaro); em verdade, uma revolução demanda, inclusive, violência e esta última não teria, por si só, como ser a "mani-

\footnotetext{
2 Neste ponto, não podemos discutir até que ponto tal interpretação sobre Hegel é pertinente. Destacamos, no entanto, que o "acerto de contas com Hegel" será um dos grandes temas durante a obra madura do autor húngaro, como em O jovem Hegel (1963) e como na Ontologia. (2013) Sobre o assunto, Cf. SARTORI, 2019.
} 
festação da sociedade utópica". Ao mesmo tempo em que surge na luta da classe trabalhadora a superação (Aufhebung) da antinomia entre meio e fim, a violência e o ato revolucionário colocam-se ao autor como uma grande questão, inclusive, de natureza moral. Levanta-se essa questão que será essencial para a compreensão dos meandros desse período da produção lukacsiana, porque ela remeterá fortemente ao modo pelo qual o autor tematiza a responsabilidade individual e a relação dos revolucionários com o processo histórico de construção do socialismo. Agora, porém, é preciso destacar aquilo que faz com que seja possível tal leitura da dialética presente em Tática e ética: trata-se da filosofia da história. Lukács menciona o "parâmetro decisivo da tática socialista: a filosofia da história"; e, aqui, certamente, está muito mais próximo de Hegel que de Marx (LUKÁCS, 1963; 2013; MARTINS, 2017). Em Marx, não há algo como uma filosofia da história, marcada por um télos; em 1919, no entanto, essa é justamente a sustentação da posição adotada por Lukács. Ou seja, diante de questões centrais, em 1919, o recurso utilizado pelo marxista húngaro é aquele que ele criticaria com força em sua maturidade, o de hipotecar a atividade humana a um télos colocado na história e que levaria ao socialismo (SARTORI, 2017).

As mediações políticas colocadas no cotidiano da luta de classes são percebidas, certamente; aponta o marxista húngaro que "há transições conceituais indetermináveis" entre os meios táticos e o fim último. E, assim, Lukács aponta em direção a uma problemática que será essencial para a conformação de todo o marxismo do século XX. Ele está ciente da questão, portanto. No entanto, ele é explícito ao destacar que, mesmo em meio há tal indeterminação, a priori, há parâmetros e medidas, trazidos na filosofia da história. Ou seja, o estudo das mediações que compõem aquilo que Hegel chamou de eticidade (Sittlichkeit) e que correspondem ao cerne das preocupações do Lukács da Estética e da Ontologia - na medida em que essas obras tematizam a especificidade das esferas do ser social e do próprio ser social - acaba não sendo central; em seu lugar, aparece o papel da filosofia da história e, como se verá, da moral, relacionada à moralidade (Moralität), tudo isso subordinado a uma visão teleológica da história. Nota-se, desse modo, que a filosofia da história e a moral acabam ocupando um papel bastante central nos textos lukacsia- 
nos de 1919; de certo modo, pode-se dizer que, ao invés da compreensão do ser-propriamente-assim (Geradesosein) da sociedade - compreensão esta que demandaria uma formação mais sólida do autor húngaro - tem-se uma correlação bastante íntima entre a ação individual (relacionada à moral e à responsabilidade) e o destino do gênero humano, trazido em uma teorização teleológica sobre a história moderna.

É certo que não se pode tratar com cuidado aqui da questão; mas deve-se destacar: justamente a postura que o autor critica em sua obra madura é aquela que adota no ano de 1919. (SARTORI, 2017; 2018a). Vale dizer, porém, que há algo muito peculiar sobre a passagem citada acima. Nela, ao mesmo tempo, o autor fala de "ultrapassar os marcos econômicos, legais e sociais da sociedade atual" e fala de "realização de ideias". A temática é bastante mediada e remete à imanência da utopia, de um lado, e, de outro, à tematização lukacsiana de 1919, ligada à relação entre a esfera econômica e a noção de dignidade humana, que seria subordinada à primeira:

Para que cesse a era da dependência diante do econômico, que humilha a dignidade humana, é preciso - como disse Marx - quebrar o poder cego das forças econômicas, e colocar em seu lugar um poder mais elevado e correspondente à dignidade do ser humano. (LUKÁCS, 2005, p. 29)

Em 1919, Lukács acredita que seria possível cessar a "dependência diante do econômico"; seria, inclusive, necessário colocar a "dignidade humana" no lugar do "poder cego das forças econômicas"; ou seja, a economia, se trouxesse dependência, aviltaria a dignidade humana.

Esta última, no capitalismo, estaria "humilhada". Pode-se mesmo dizer que essa seria uma daquelas ideias a se tornar imanente. Ao que parece, a utopia de que fala Lukács, em meio aos ideais vacilantes, pode ser relacionada à noção de "dignidade humana". O marxismo traria consigo, na visão do autor, a conversão do "objeto transcendente em imanente". Desse modo, a própria potência econômica não traria mais dependência. A questão é importante, pois implica uma leitura peculiar, que traz o socialismo como o resultado imanente da luta de classes, ao mesmo tem- 
po em que realiza a dignidade humana, somente possível quando cessa a "dependência" frente à economia. Tal leitura é bastante particular e é típica da visão de mundo (Weltanschauung) do autor na época; tal visão, no entanto, toma a dependência diante da esfera produtiva como um fato histórico e transitório, e não como algo que exige uma transformação na forma pela qual se dá essa dependência, o que remete a toda uma teorização - ausente no autor na época - sobre a autogestão dos trabalhadores e sobre o controle consciente da vida cotidiana (SARTORI, 2017).

Essa posição (Standpunkt), que enfatiza a dignidade humana e que critica toda a dependência diante do elemento econômico, será bastante criticada por Lukács a partir da década de 1930 (MÉSZÁROS, 1972). Ela é substancialmente distinta daquela presente em Marx, para quem, não obstante trate-se de buscar o "reino da liberdade" com o comunismo, esse "reino" sempre tem por base a dependência econômica colocada no "reino da necessidade". Marx também não fala de "dignidade humana" (MARX, 1986a). Ele aponta como tarefa a busca por condições de produção materiais, em que se tenha uma forma de dependência diante da "natureza externa", com condições "mais dignas e adequadas à natureza humana” (MARX, 1986a, p. 273). Deve-se destacar, porém: em Marx, trata-se de buscar redução da jornada de trabalho e nunca a supressão (Aufhebung) da dimensão econômica e da produção material propriamente dita, que permanece ligada sempre ao "reino da necessidade"3. O autor

${ }^{3}$ Diz Marx (1986a, p. 273), em $O$ capital: “[...] a riqueza real da sociedade e a possibilidade de constante expansão de seu processo de produção não depende, portanto, da duração do mais-trabalho, mas de sua produtividade e das condições mais ou menos ricas de produção em que ela transcorre. O reino da liberdade só começa, de fato, onde cessa o trabalho determinado pela necessidade e pela adequação a finalidades externas; portanto, pela própria natureza da questão, isso transcende a esfera da produção material propriamente dita. Assim como o selvagem tem de lutar com a Natureza para satisfazer suas necessidades, para manter e reproduzir sua vida, assim também o civilizado tem de fazê-lo, e tem de fazê-lo em todas as formas de sociedade e sob todos os modos de produção possíveis. Com seu desenvolvimento, amplia-se esse reino da necessidade natural, pois se ampliam as necessidades; mas, ao mesmo tempo, ampliam-se as forças produtivas, que as satisfazem. Nesse terreno, a liberdade só pode consistir em que o homem social, os produtores associados, regulem racionalmente esse seu metabolismo com a Natureza, trazendo-o para seu controle comunitário, em vez de serem dominados por ele como se fora por uma força cega; que o façam com o mínimo emprego de forças 
alemão também não traz a natureza humana como um ideal, mesmo que vacilante, a ser realizado, mas como o conjunto de determinações do ser social em meio ao desenvolvimento histórico, já "que toda a história não é mais que uma transformação contínua da natureza humana" (MARX, 1986b, p. 138). Ao modificar a "natureza externa", o homem também "modifica, ao mesmo tempo, sua própria natureza" (MARX, 1996, p. 297). Ou seja, Marx pode ser considerado um "pensador da imanência" (MARTINS, 2017), não porque os ideais transcendentes se tornam imanentes, mas porque, em verdade, não se trataria de "realizar ideais". Ao mesmo tempo em que Lukács afirma certa concepção de utopia que pretende escapar do idealismo, ele parece não estar consciente da natureza bastante mais meandrada da dependência econômica. Algo que é ausente no texto lukacsiano de 1919 é a necessidade da transformação substantiva da produção social no sentido da "produção associada" (MARX, 1986a). Dessa maneira, ao que tudo indica, a ênfase na moral e na filosofia da história têm uma relação bastante íntima com tal ausência; como será mostrado, posteriormente, ao analisar o Direito e sua relação com a moralidade, a temática aparece de modo bastante concreto na tematização do autor húngaro.

Pode-se dizer, neste ponto do texto, que, talvez, as questões estejam intimamente conectadas em sua obra de 1919. Aqui, a medida da práxis social não é tanto a apreensão do ser-propriamente-assim (Geradesosein) do ser social e de suas possibilidades concretas, mas a filosofia da história, em que a dignidade humana aparece como algo a ser realizado. O polo central de seu texto, assim, liga-se a uma concepção teleológica de história. Parece que o apelo lukacsiano a Hegel e à moral (expressa aqui já na noção de dignidade humana) tem como contraparte certa apreensão imatura da crítica marxiana à economia política, com todas as implicações desta. Assim, como marxista, Lukács tem ainda uma formação

e sob as condições mais dignas e adequadas à sua natureza humana. Mas este sempre continua a ser um reino da necessidade. Além dele é que começa o desenvolvimento das forças humanas, considerado como um fim em si mesmo, o verdadeiro reino da liberdade, mas que só pode florescer sobre aquele reino da necessidade como sua base. A redução da jornada de trabalho é a condição fundamental. Para uma análise cuidadosa da questão, ver Sartori (2018b). 
incipiente, precisando apelar a Hegel, à teologia (essa questão será vista mais à frente) e a concepções que remetem à tradição teológica na medida mesma em que passam pela moral. Sua obra de 1919 é de difícil compreensão, no entanto, algo já pode ser dito desde já: aquilo que o autor criticaria fortemente em sua obra madura - na Estética e na Ontologia - aparece em destaque. O panorama sobre o qual se colocam os textos lukacsianos de 1919 é dramático. A Primeira Guerra acaba de terminar e a Revolução Russa estoura, e vem se consolidando. Tais textos aqui tratados são o resultado de um posicionamento firme diante desses grandes eventos do início do conturbado século XX.

\section{Responsabilidade Comunista, Moral e Revolução}

Um dos polos do pensamento lukacisno está na filosofia da história. Outro, porém, está na pauta moral. Uma temática essencial em 1919 é a culpa e a responsabilidade individuais, as quais estão presentes tanto na tradição cristã quanto nas obras de Dostoiévski, aspectos estes estudados pelo autor húngaro no período anterior aos textos aqui estudados (TERTULIAN, 2008). Nesse sentido, os temas que foram essenciais à sua teoria estética e aos seus estudos sobre o drama aparecem aqui com uma feição distinta, ligada às mediações da atividade humana colocada no campo político. Veja-se a relação desses temas com o comunismo e com a revolução:

Tudo aquele que se diz atualmente comunismo está comprometido a carregar a mesma responsabilidade individual por cada vida humana que morre por sua causa em luta, e que lhe toca do mesmo modo como se ele tivesse sido morto. Mas todos que aderem ao outro lado - a defesa do capitalismo - devem carregar com a mesma responsabilidade individual pela destruição que se produz nas novas guerras imperialistas, que certamente serão geradas em represália [às revoluções socialistas], tal qual pela opressão futura das nações e classes. Eticamente, ninguém pode fugir da responsabilidade alegando ser meramente um indivíduo, do qual não depende o destino do mundo. Isto não temos como saber com certeza - pode ser que o destino do mundo dependa precisamente deste indivíduo 
-, mas, inclusive, a essência mais íntima da ética, a consciência e o senso de responsabilidade, tornam impossível um pensamento semelhante; quem não toma uma decisão sobre a base destas considerações - ainda que se mostre como muito evoluído -, encontra-se, do ponto de vista da ética, no nível do instinto primitivo, inconsciente. (LUKÁCS, 2005, p. 32)

Lukács traz uma combinação entre a responsabilidade individual e a filosofia da história. A questão é bastante interessante porque o télos colocado na história não justifica todos os atos. Isso se dá porque a luta de classes da classe trabalhadora teria consigo a superação imanente da oposição entre meios e fins; no entanto, a temática apareceria também na medida em que o apoio à revolução seria também algo ligado à responsabilidade moral individual.

Para o autor, portanto, só é possível dizer que a luta da classe trabalhadora "representa uma nova manifestação da sociedade utópica", porque cada indivíduo deveria estar disposto a assumir o ônus de "cada vida humana que morre por sua causa em luta". Há, portanto, uma correlação íntima entre dois polos normalmente vistos como apartados, a ação individual e o sentido da transformação histórica. A questão é dúplice: de um lado, coloca-se em tela algo que é essencial ao considerar a conformação objetiva da totalidade social, a ação individual. De outro lado, porém, há certo abismo - que Lukács tenta transpor por meio da noção de responsabilidade - entre a moral e a transformação revolucionária. Novamente, nota-se que a oposição entre a moralidade (Moralität) e a eticidade (Sittlichkeit) não é trazida à tona para que se valorize a última; e, em sua obra madura, ele buscará a passagem da primeira para a segunda, criticando a centralidade da moralidade no stalinismo e na filosofia burguesa (SARTORI, 2017) Antes, nos textos de 1919, a superioridade do socialismo frente ao capitalismo é colocada em termos bastante marcantes: tanto os que defendem um sistema social quanto os que defendem o outro deveriam "carregar a responsabilidade individual" pelas mortes e catástrofes. Seria, porém, muito distinto carregar a responsabilidade pelas "novas guerras imperialistas" (que se ligam à “opressão futura das nações e classes") de um lado, e, de outro, carregar a responsabilidade daquele que se 
coloca ao lado da filosofia da história e que, assim, liga-se à "nova sociedade utópica". Diz o autor, assim, que "ninguém pode fugir da responsabilidade alegando ser somente um indivíduo" ao mesmo tempo em que coloca os indivíduos diante de escolhas ligadas à violência mais bruta; de um lado, a violência revolucionária, de outro a das guerras imperialistas. A era em que os indivíduos se desenvolveriam seria aquela da "pecaminosidade consumada" (LUKÁCS, 2005), expressão que Lukács empresta de Fichte para retratar a efetividade da sociedade capitalista, em um tom que não deixa de remeter à teologia.

Percebe-se, pois, que a luta da classe trabalhadora é a expressão da "nova sociedade utópica", ao mesmo tempo, o que se apresenta aí é uma inelutável relação com a violência das sociedades classistas. Ou seja, o percurso da "filosofia da história", que serviria como garantia da práxis revolucionária, não seria nada linear. Os meandros da temática têm uma tonalidade dramática para o autor húngaro. Diante da questão da responsabilidade individual por todas as vidas perdidas, "quem não toma uma decisão sobre a base destas considerações" traria uma postura extremamente questionável e reprovável: "encontra-se, do ponto de vista da ética, no nível do instinto primitivo, inconsciente". A postura lukacsiana, em 1919, assim, é aquela em que o parâmetro ético é trazido pela ação moral, relacionada à responsabilidade individual. Tem-se, de um lado, uma crítica à conceituação hegeliana sobre a suprassunção (Aufhebung) da moral na eticidade - sempre, em Tática e ética, a dimensão moral permanece ligada ao indivíduo que se coloca diante do mundo em meio à sua responsabilidade; de outro lado, há uma correlação bastante direta entre a ação individual e a filosofia da história. Isso faz com que a concepção lukacsiana da época seja bastante peculiar, tendo-se, tal qual em Dostoiéviski (essencialmente, mas não só em Crime e castigo), uma correção entre o agir, a culpa e a responsabilidade quanto aos próprios atos.

A ciência, o conhecimento, somente podem mostrar possibilidades; e uma ação moral, carregada de responsabilidade, uma verdadeira ação humana se encontra só no solo do possível. Mas, para aquele que capta essa possibilidade, não existe, se é socialista, nenhuma opção ou vacilação. Isto, no entanto, não pode querer dizer que a 
ação assim constituída deva ser já forma necessária moralmente incorrupta e intocável. Nenhuma ética pode ter por fim encontrar receitas para a ação correta, suavizar e negar os conflitos insuperáveis, trágicos do destino humano. Ao contrário: o autoconhecimento ético sinaliza, precisamente, que há situações trágicas nas quais é impossível atuar sem carregar culpa.; ao mesmo tempo, também nos ensina que ainda nos casos em que tivermos que eleger formas de culpabilidade, existirá um parâmetro para a ação correta ou incorreta. (LUKÁCS, 2005, p. 32)

Entre a possibilidade (Möglichkeit) e a efetividade (Wirklichkeit), na obra de Lukács de 1919, coloca-se a responsabilidade individual e, portanto, a moralidade. A ciência, assim, poderia ser muito importante para que se desvendassem as possibilidades objetivas; no entanto, quando se trata de responsabilidade, a questão seria essencialmente moral, não havendo "nenhuma opção ou vacilação". Se uma marca característica da obra madura lukacsiana será destacar a existência de alternativas concretas diante da atividade humana, aqui, tais alternativas têm um peso moral muito forte e são conformadas de modo sui generis: para o autor, em verdade, "se é socialista", não há alternativas a serem ponderadas, mas um forte senso de dever e de responsabilidade.

Os meandros do tema, porém, são muitos. Mesmo que não possa existir nenhuma "opção ou vacilação", há "conflitos insuperáveis" colocados na dimensão moral. E mais, "nenhuma ética pode ter por fim encontrar receitas para a ação correta"; antes, segundo Lukács, a ética vem justamente para reconhecer o elemento trágico que seria ineliminável na moral. Haveria, assim, "conflitos insuperáveis, trágicos do destino humano". E, dessa maneira, a ausência de vacilação e de opção dos socialistas configurar-se-ia também na necessidade de carregar a culpa. Diz o autor húngaro que "o autoconhecimento ético sinaliza, precisamente, que há situações trágicas nas quais é impossível atuar sem carregar culpa"; a ética, assim, somente seria capaz de explicitar as situações moralmente dramáticas pelas quais os indivíduos devem passar caso efetivamente se coloquem como socialistas. A ética não pode ser outra coisa que a assunção moral da tragédia do presente para que esta cesse. 


\section{4 Ética, Pecado e Revolução}

A ética conformada nos textos lukacsianos de 1919 tem uma dimensão trágica. A ação moral é aquela que, do ponto de vista da filosofia da história, é a única capaz de romper com o presente; ao mesmo tempo, a dimensão da responsabilidade e da culpa individuais paira sobre toda ação que seja condizente com a ética. Isso se dá, também, porque na época da "pecaminosidade consumada", o pecado não poderia deixar de marcar todas as existências individuais. Todos, desse modo, carregariam a culpa relacionada à existência da sociedade capitalista. A questão, assim, seria saber de que lado se colocar concretamente. E, novamente, nesse ponto aparece o parâmetro da filosofia da história; pode-se dizer, assim, que grande parte das futuras críticas de Lukács ao teleologismo atingem sua própria obra "de juventude". O autor foi explícito quanto a isso no posfácio de História e consciência de classe (LUKÁCS, 2003). No entanto, a questão é ainda mais clara quando se trata de seus textos de 1919. $\mathrm{O}$ apelo lukacsiano à moral, aqui, passa muito próximo, de um lado, a uma compreensão marcada por uma filosofia teleológica da história; de outro lado, relaciona-se à ênfase na ação individual, marcada pela necessidade de carregar a culpa e a responsabilidade moral. Dessa maneira, uma grande questão seria "eleger formas de culpabilidade", restando bastante explícito como que a própria existência na sociedade capitalista, se marcada pela busca pela autenticidade, traria consigo um senso, ao mesmo tempo, trágico e revolucionário.

Essa combinação sui generis aparece no autor quando ele diz que tal situação, "ao mesmo tempo, também nos ensina que ainda nos casos em que tivermos que eleger formas de culpabilidade, existirá um parâmetro para a ação correta ou incorreta"; no que a dependência do autor diante da crença em uma filosofia teleológica da história fica mais clara ainda. A ética lukacsiana, em 1919, é aquela em que há a necessidade de aceitar a culpa decorrente da obrigação de realizar atos inaceitáveis moralmente; daí, a dimensão trágica da ação revolucionária, que o autor chega a equacionar, após ter chamada sua época daquela da "pecaminosidade consumada", em termos abertamente teológicos, algo que também criticará pesadamente em sua obra madura: 
Em outras palavras: só o crime realizado por um homem que sabe firmemente e sem nenhuma dúvida que o assassinato não pode ser aprovado em nenhuma circunstância, pode ser - tragicamente - de natureza moral. Para expressar o pensamento da mais forte tragédia humana em inimitáveis belas palavras de Judith a Hebbel: 'E se Deus tiver colocado entre mim e minha missão, que me foi designada, quem sou eu para me insurgir contra ele?' (LUKÁCS, 2005, p. 34)

Antes, havia sido mencionada a responsabilidade por cada morte decorrente da luta que se dá na sociedade capitalista. Lukács traz à tona que a culpa, assim, marca todos os indivíduos; também aponta para o elemento trágico da ação que se dá na sociedade capitalista. Seria, assim, preciso eleger as "formas de culpabilidade" a serem assumidas pelos indivíduos. A revolução, desse modo, assumiria a marca da violência, que mutila a sociedade capitalista. Não haveria como escapar disso. A ação revolucionária - que é o cume da luta de classes da classe trabalhadora -, não obstante conseguisse superar a antinomia entre meios e fins, traria consigo, ao mesmo tempo, uma "nova sociedade utópica" e a consciência de que, individualmente, a violência revolucionária não poderia ser aprovada em nenhuma circunstância. E, também aqui, a "pecaminosidade consumada" aparece.

Diante da pecaminosidade, a ação moral seria aquela que estivesse consciente da situação dramática da sociedade capitalista. O crime, assim, estaria ligado à conduta moral, já que somente quando se sabe "sem nenhuma dúvida" que a violência revolucionária - da perspectiva individual - liga-se ao assassinato e que este "não pode ser aprovado em nenhuma circunstância" é que se tem um crime de natureza moral. Lukács não afasta a acusação de "crime" que é levada aos revolucionários. Pode-se dizer que - tragicamente - ele assume tal acusação e a incorpora como parte da ação efetivamente moral sob o modo de produção capitalista. A expressão "da mais forte tragédia humana" estaria justamente na bíblia (e na literatura), em que o pecado pode se colocar entre a missão atribuída por Deus e a ação individual; a solução para a questão estaria justamente em assumir o pecado como parte da própria missão divina: “e se Deus tiver colocado entre mim e minha missão, que me foi designada, quem sou eu 
para me insurgir contra ele?'. Explicitamente, portanto, a ética lukacsiana de 1919 traz consigo um elemento teológico. A temática da responsabilidade moral passa pela culpa, pelo pecado, e a revolução haveria de passar por esses momentos para que pudesse se tornar uma realidade efetiva. Novamente, aquilo que Lukács criticará com força no momento posterior à Segunda Guerra aparece aqui com muita força; também, nesse sentido, a obra posterior do autor húngaro pode ser vista como permeada por autocríticas fortes. Tanto o apego à moral quanto o ponto de vista mais ou menos teológico, essenciais a esse momento de sua obra, serão repudiados posteriormente pelo autor da Ontologia do ser social.

\section{Direito, Moral e Luta de Classes}

Ao tratar da moral, um tema importante que vem à tona é aquele do Direito. A centralidade que tem a questão moral na obra lukacsiana de 1919 não poderia deixar de levar a uma teorização sobre o elemento jurídico da vida social, indissociável do aspecto estatal. Seguindo Engels - em Origem da família, da propriedade privada e do Estado - Lukács afirma tanto a necessidade da regulamentação jurídica nas sociedades classistas quanto a supressão do Direito no comunismo. No entanto, é bastante peculiar o modo pelo qual o autor húngaro equaciona a temática:

Enquanto existirem diversas classes, é inevitável que a função de regular a atividade social seja assumida pelo Direito, e não pela moral. No entanto, essa função do Direito não se esgota em obrigar as classes oprimidas a realizar uma atividade em benefício dos opressores. Os interesses classistas das classes dominantes devem mostrar validade inclusive aos olhos da classe dominante. Esta segunda fonte para a necessidade do Direito, a contradição entre os interesses individuais e os interesses de classe não é só uma consequência da divisão da sociedade em classes. É verdade que, sem dúvida, esta contradição nunca foi tão aguda quanto sob o capitalismo. As condições de existência da sociedade capitalista - a anarquia da produção, a ininterrupta revolução na produção, a produção baseada em benefício econômico - excluíram de antemão a possibilidade de os interesses individuais e classistas se unirem harmoni- 
camente dentro de uma classe. [...] Nas classes capitalistas só pode existir uma solidariedade de classe para fora, mas não para dentro. Por isso, a força do Direito nunca pode ser substituída pela moral no interior desta classe. (LUKÁCS, 2005, p. 65)

Uma peculiaridade da posição lukacsiana de 1919 é que a supressão do Direito passa pela substituição deste pela moral. Essa postura, além de não poder ser encontrada em Marx, será explicitamente criticada pelo próprio Lukács posteriormente (SARTORI, 2017; 2018a). Segundo o autor, na sociedade comunista, ao que parece, o papel que é ocupado pelo Direito - que se colocaria como uma espécie de coerção externa - seria substituído pela moral. Esta última, por sua vez, poderia trazer uma espécie de "solidariedade" que se colocasse "para dentro".

No capitalismo, assim, a regulamentação jurídica nunca poderia ser substituída pela moral porque a própria "anarquia da produção" traz consigo que a coerção social se impõe aos homens, humilhando-os e aviltando a dignidade humana. Como já mencionado, de acordo com o autor de Tática e ética, "para que cesse a era da dependência diante do econômico, que humilha a dignidade humana, é preciso - como disse Marx - quebrar o poder cego das forças econômicas, e colocar em seu lugar um poder mais elevado e correspondente à dignidade do ser humano". No comunismo, a oposição entre a dignidade humana e o "poder cego das forças econômicas" findaria, sendo possível, como correlata, não mais uma regulamentação externa à atividade dos homens, mas, por assim dizer, interna. E aí a questão acaba levando a meandros da atividade econômica, que, em sua complexidade, aqui, não é tratada por Lukács, também, devido à formação insipiente do autor.

Mais à frente, será dada maior atenção à produção na concepção lukacsiana. Pode-se dizer agora, no entanto, que o Direito, para Lukács, não se resume simplesmente a uma espécie de coerção externa sem contato algum com a vida das classes oprimidas. É verdade que o autor não defende como solução para a "pecaminosidade consumada" a regulamentação jurídica. Nada passa mais longe do marxista húngaro. No entanto, o autor reconhece que a função do Direito não está restrita à opressão crua 
das classes dominantes diante das oprimidas. Uma questão muito importante aparece quando "os interesses classistas das classes dominantes devem mostrar validade inclusive aos olhos da classe dominante" por meio da regulamentação jurídica. Ou seja, a função realizada pelo Direito é, ao mesmo tempo, aquela de um veículo da dominação classista direta e aquela que faz com que tal dominação apareça, até certo ponto, como legítima aos próprios explorados.

Isso precisa ser destacado, pois remete tanto a uma compreensão mais mediada do fenômeno jurídico por parte de Lukács, se comparado a outros marxistas, quanto a uma diferente visão sobre o pano de fundo que traz o Direito como uma necessidade. Ambas as questões são essenciais.

A primeira delas leva o autor húngaro, já em 1919, a escapar de simplificações: mesmo que o apelo moral lukacsiano possa ser considerado extremamente problemático - já que tem como base uma visão que não deixa de ser teológica, e que remete à responsabilidade individual como algo central diante de uma filosofia teológica da história - ele decorre, também, da apreensão de um problema bastante real: a transição soviética não parecia estar conseguindo dar conta de grandes problemas trazidos à tona por Marx e Engels, principalmente, no que se refere ao fenecimento do Estado e do Direito. Por mais que a solução lukacisiana possa ser vista como bastante distinta daquela que, do ponto de vista marxista, seria desejável (segundo o próprio autor), ela levanta problemas sérios. Um deles vem à tona ao passo que a existência de classes sociais e do Direito é vista como inseparável. E mais, o Direito justamente tem como pano de fundo a oposição entre o interesse individual e o interesse classista. $\mathrm{O}$ pano de fundo mais geral para se tratar da regulamentação jurídica é, portanto, a contradição entre indivíduos (e sua moral) e as classes sociais; e isso, até onde se pode compreender, poderia se dar, segundo Lukács, inclusive em meio à transição socialista que se opera na URSS. Também em meio a esta, a "solidariedade de classe", mesmo que em menor grau, aparece como uma "solidariedade de classe para fora, mas não para dentro". 
Mesmo em meio à transição, portanto, "a força do Direito nunca poderia ser substituída pela moral". A existência das classes sociais, do Direito e de certas contradições dentro do proletariado são tematizadas por Lukács de modo que o autor diz o seguinte sobre a moral e o Direito:

Uma vez que já não existam classes, a ditadura já não pode ser exercida contra ninguém. Com isso, cessa de existir o Estado, a principal causa do exercício da compulsão jurídica; aquela causa que Engels tinha em mente quando disse que 'o Estado fenece'. A pergunta é, no entanto, como se dá esta evolução dentro da classe proletária? Aqui surge o problema da função socialmente efetiva da moral; tal pergunta desempenhou, sem dúvida, um papel importante nas ideologias da velha sociedade, mas nunca contribuiu essencialmente para a própria construção da realidade social. Não podia tê-lo feito, pois os pressupostos sociais da ação moral de classe e de seu valor dentro de uma classe - a saber, orientação igual dos interesses individuais e de classe - só estão presentes no proletariado. A solidariedade, a suspensão dos interesses pessoais diante dos coletivos, somente no caso do proletariado coincidem com o interesse individual adequadamente concebido. Aqui, pois, está dada a possibilidade social de que todos os indivíduos pertencentes ao proletariado se subordinem aos interesses da classe sem prejuízo de seus interesses pessoais. Uma tal atitude livre de coerção era impossível na burguesia. Ali, uma regulação só poderia ser imposta pelo Direito. (LUKÁCS, 2005, p. 65)

Lukács relaciona a compulsão jurídica com a existência das classes sociais e faz uma pergunta essencial sobre a evolução do fenecimento do Estado e do Direito: "como se dá esta evolução dentro da classe proletária?”. A pergunta é de grande importância e se relaciona ao papel que o autor húngaro atribui à moral, mais precisamente à "função socialmente efetiva da moral".

Ou seja, as temáticas tratadas anteriormente se relacionaram à derrubada do capitalismo, ao uso da violência e à "pecaminosidade" envolvida nisso. Aqui, porém, há certa continuidade, que está mas ligada à transição, em que o autor húngaro traz uma formulação - decorrente de Engels - e bastante problemática do ponto de vista marxista (SARTORI, 2016), 
ligada a uma moral de classe, em que haveria, no caso do proletariado, uma confluência entre os interesses individuais e aqueles da classe social. Tal questão, tal qual no caso do autor do Anti-Düring, mas com o pano de fundo da Revolução Russa, aparece sobre a base de dificuldades diante da temática do fenecimento do Estado (SARTORI, 2016). Caberia, diante dessas dificuldades concretas, saber que papel a compulsão jurídica e a moral poderiam ter na transição. Tratar disso tendo em conta a classe trabalhadora poderia ser muito importante, pois até agora, segundo o autor de Tática e ética, "tal problema [...] nunca contribuiu essencialmente para a própria construção da realidade social".

Isso teria ocorrido porque somente com a transição estaria dada a base real para uma ação moral de classe, a saber, a "orientação igual dos interesses individuais e de classe". No que, assim, a moral proletária é trazida por Lukács em termos que não deixam de trazer, mesmo que de modo mediado, uma temática teológica, a "suspensão dos interesses pessoais diante dos coletivos".

Há uma continuidade bastante grande entre aquilo que é trazido pelo autor na supressão do capitalismo e em meio à transição, pois. E, dessa maneira, o elemento moral vem a ser central em ambos os casos. Uma questão importante nesse ponto são os meandros do tema, que aparecem quando o marxista húngaro não relaciona ingenuamente o interesse individual com o interesse classista; ele traz uma relação íntima entre o último e o "interesse individual adequadamente concebido"; a moral proletária, assim, traria consigo uma espécie de coerção de classe, e, assim, muito mais "interna" que aquela do Direito. Porém, uma dificuldade enorme aparece aqui.

O parâmetro para isso não seria tão diretamente apreensível e, assim como ocorreu acima, tem-se por essencial o parâmetro da filosofia da história. Os diversos problemas relacionados a essa posição e presentes no seio do movimento socialista do século XX são patentes e foram parte essencial do movimento comunista do século passado (CLAUDIN, 2013). Não é possível tratar do tema aqui; mas pode-se trazer a temática ao mostrar que, mesmo nos textos lukacsianos de 1919, já se discutia o 
problema - é verdade que com uma tonalidade moral, individualista e teológica - sendo válido trazer à tona o que diz o autor sobre o assunto:

Este ponto no qual confluem o interesse individual e o de classe é, pois, o incremento da produção, o aumento da produtividade laboral e, com ela, da disciplina do trabalhador. Sem estes fatores, o proletariado não pode existir, sem eles, a hegemonia de classe se esfacela; [...] Em última instância, se procura uma ordem jurídica através da qual o proletariado obriga as individualidades, os proletários, a atuar de acordo com seus interesses de classe: o proletariado aplica a ditadura sobre si mesmo. Esta prescrição é necessária para a preservação da vida do proletariado, se não estão dados o conhecimento apropriado e a filiação voluntária aos interesses de classe. Mas não há de se ocultar que este caminho traz perigos para o futuro. Se o proletariado mesmo cria uma disciplina laboral, se a organização do trabalho por parte do Estado operário se edifica sobre a base de um fundamento moral, então cessa automaticamente, junto com a eliminação da divisão em classes, a coerção externa do Direito; quer dizer, o Estado se extingue. [...] Se, por outro lado, o proletariado segue um caminho diferente e tem que criar para si uma ordem jurídica que não pode ser eliminada automaticamente pela evolução histórica. A evolução tenderia, pois, a um caminho que colocaria em perigo a manifestação e a realização do fim último. Pois aquela ordem jurídica que o proletariado se vê obrigado a criar desta maneira, deve ser abolida; e quem sabe que comoções e padecimentos ocasionará, em meio a estes meandros, aquela transição do reino da liberdade ao reino da liberdade? (LUKÁCS, 2005, p. 67)

Lukács havia dito anteriormente que "o fim último do socialismo é utópico no sentido de que ultrapassa os marcos econômicos, legais e sociais da sociedade atual"; quando se trata da transição, no entanto, a questão se coloca de modo um tanto quanto distinto, já que a confluência do interesse individual com o de classe é "o incremento da produção, o aumento da produtividade laboral e, com ela, da disciplina do trabalhador". E, assim, seria preciso questionar se, nesse caso, não deixa de permanecer a "era da dependência diante do econômico, que humilha a 
dignidade humana". Não seria a disciplina laboral colocada na moral de classe também algo relacionado com "o poder cego das forças econômicas"? Seria possível sob essa base "colocar [...] um poder mais elevado e correspondente à dignidade humana"? A equação moral da questão faz com que as esperanças "utópicas" de Lukács sejam bastante discrepantes daquilo que ele mesmo vem a propor na transição; se ele diz que na luta de classes do proletariado deixa de existir uma oposição entre meios e fins, para afirmá-lo, precisa de uma teoria sobre a moral que, além de se basear fortemente em uma filosofia teleológica da história, não deixa de trazer certa tonalidade teológica em postos específicos. A justificativa lukacsiana da ditadura do proletariado, em 1919, é, também, moral.

O modo pelo qual o interesse classista e o "interesse individual adequadamente concebido" se harmonizam, no entanto, mesmo que passe pela moral proletária, precisa do Direito. Por isso, diz o autor que "em última instância, se procura uma ordem jurídica através [da] qual o proletariado obriga as individualidades, os proletários, a atuar de acordo com seus interesses de classe: o proletariado aplica a ditadura sobre si mesmo". Tal caminho seria necessário e, ao mesmo tempo, perigoso.

Isso, até certo ponto, vai contra aquilo que o próprio Lukács defendeu. A centralidade da moral é patente em seu pensamento da época, de modo que o mesmo que o autor disse sobre o pecado e a missão é válido aqui: se a imposição da coerção externa é característica da burguesia, ela precisaria ser usada contra o próprio proletariado, caso isso fosse necessário para a missão comunista, e ligada à supressão da coerção externa presente no Direito. A questão tem certa tragicidade, portanto.

Mesmo que com ressalvas, o autor húngaro vem a dizer que "o proletariado aplica a ditadura sobre si mesmo". Para atuar realmente de acordo com seus interesses de classe, não basta a moral, portanto: é necessário, mesmo que extraordinariamente, remeter ao "Estado operário" e ao Direito. Isso seria necessário, de um lado, para que a "hegemonia de classe" do proletariado não se esfacelasse e, de outro, para "preservação da vida do proletariado, se não estão dados o conhecimento apropriado e a filiação voluntária aos interesses de classe". Parece que, de acordo com tal raciocínio, pode-se dizer sobre um revolucionário e a repressão ao 
próprio proletariado, parafraseando o que foi dito sobre o pecado: e se a história tiver colocado entre mim e minha missão, que me foi designada, quem sou eu para me insurgir contra ela? O "parâmetro" da filosofia da história, nesse ponto, não poderia ser mais perigoso; e o próprio Lukács reconhece isso, ao dizer que "não há de se ocultar que este caminho traz perigos para o futuro".

Aqui não é possível tratar desses perigos, mas há de se apontar que eles foram bastante presentes na história do movimento comunista do século XX (CLAUDIN, 2013; LUKÁCS, 2013). Para o que nos diz respeito neste pequeno texto, é preciso afirmar que o caráter, ao mesmo tempo, trágico e revolucionário presente na compreensão lukacsiana da ética aparece aqui ao tematizar a relação entre moral e Direito em meio ao processo de transição.

Para o nosso autor, parece que, mesmo que de maneira trágica, ao aplicar a ditadura ao próprio proletariado, cria-se o fundamento moral para o fenecimento do Direito e para a hegemonia da própria moralidade. A disciplina laboral do proletariado, segundo Lukács, poderia ter um fundamento moral de tal modo que a "coerção externa do Direito" poderia ser deixada de lado, tendo-se a necessidade dessa coerção somente para que se criasse as condições para a supressão do Direito. A regulamentação jurídica, assim, teria uma função muito diferente do que se passa na sociedade capitalista: sua função em meio à transição seria resguardar a confluência entre o interesse individual e o de classe, garantindo a hegemonia do proletariado. Pode-se dizer que, segundo o Lukács de 1919, o Direito passa a exercer uma função intimamente ligada à moral da classe trabalhadora, na qual se pode exigir coerentemente sacrifícios em que se tem "a solidariedade, a suspensão dos interesses pessoais diante dos coletivos".

Agir de acordo com a filosofia da história seria justamente trazer à tona esse movimento sem que ele fosse mais que algo transitório e que, real e efetivamente, levasse à eliminação das classes sociais e da coerção jurídica externa do Direito. O perigo, porém, sempre bateria à porta.

$\mathrm{O}$ autor é bastante vacilante quanto a isso. Se tal ordem jurídica não levasse quase que automaticamente à sua extinção, ter-se-ia um proble- 
ma enorme. E qual seria a garantia diante disso? A filosofia da história? A moral proletária? O senso de responsabilidade individual?

Percebe-se que o tom idealista do texto lukacsiano, em alguns momentos, é bastante forte. A própria formulação lukacsiana das questões, em 1919, como já foi dito, é bastante problemática. Diz o autor que existe uma alternativa (mesmo quando, em verdade, "não existe, se é socialista, nenhuma opção ou vacilação"): "o proletariado segue um caminho diferente e tem que criar para si uma ordem jurídica que não pode ser eliminada automaticamente pela evolução histórica". Aí, ter-se-ia uma situação que "colocaria em perigo a manifestação e a realização do fim último". E isso se dá ao mesmo tempo em que Lukács diz que, de acordo com o parâmetro da filosofia da história, não haveria oposição entre meios e fins na luta de classes da classe trabalhadora.

A questão, assim, seria igualmente trágica, pois "aquela ordem jurídica que o proletariado se vê obrigado a criar dessa maneira deve ser abolida; e quem sabe que comoções e padecimentos ocasionará, em meio a estes meandros, aquela transição do reino da liberdade ao reino da liberdade?". Seria possível perguntar também que comoções e padecimentos seriam ocasionados caso essa passagem não se realizasse diante da preservação da ordem jurídica criada na transição e diante da imposição, por meio da coerção externa do Direito, da disciplina na produção. A resposta, agora, no século XXI, já é conhecida. No entanto, segundo o que foi visto aqui, há de se perceber que uma crítica moral ao ocorrido nas sociedades alinhadas à URSS, tal qual ocorre em Lukács em 1919 (no começo do processo de conformação dessas sociedades), traz como outro lado a sombra do perigo que pretende evitar. Ou seja, talvez o velho Lukács esteja correto quando, ao revisar sua obra e o século XX, tece uma crítica à centralidade da moral (SARTORI, 2017).

\section{Conclusão}

Para que fique mais claro: a centralidade que adquire a moral no pensamento do marxista húngaro, em 1919, passa longe de trazer qualquer tipo de alternativa real às vicissitudes que vinham se desenvolvi- 
mento em meio à Revolução Russa. Em verdade, em meio à percepção dos perigos que se delineavam, justamente a posição fortemente ligada a uma ética trágica e revolucionária trouxe a justificação - bastante sofisticada, é verdade - da repressão ao próprio proletariado. Na ausência de um tratamento cuidadoso das questões colocadas para a especificidade da transição soviética - baixo desenvolvimento de forças produtivas, guerra civil, necessidade de incrementação da burocracia e do exército, entre outras questões - o autor traz uma crítica moral, que não deixa de levar a uma forma de argumentação teológica e marcada por um ethos trágico.

A formação marxista ainda insipiente de Lukács fez com que ele se posicionasse diante da Revolução Russa por meio de um aparato bastante sofisticado, mas ainda eclético. Uma das consequências foi a centralidade que adquiriu a questão moral, relacionada a uma ética que reconhece como inerente à ação humana uma dimensão trágica, marcada, ao mesmo tempo, pela necessidade de superação da oposição entre meios e fins e pelo abismo existe entre estes dois.

Por mais sedutor e interessante que possa parecer tal raciocínio, como já foi mencionado, ele foi explícita e veementemente criticado pelo próprio autor húngaro em suas principais obras da maturidade. Aqui, foi trazida essa formulação da questão, primeiramente, porque esse momento da obra lukacsiana ainda não foi estudado com o devido cuidado; no entanto, é bom ressaltar que o modo pelo qual se coloca a crítica ao capitalismo em meio à centralidade da moral não deixa de remeter a aporias que parecem intransponíveis, tal qual destacou o próprio Lukács em suas obras maduras. Se isso é verdade, a heterodoxia lukácsiana de 1919 remete a um tratamento, ao mesmo tempo, bastante interessante, meandrado e que reconhece problemas reais; mas que deixa de lado justamente um tratamento cuidadoso da crítica à economia política, esta última que, em nossa opinião, poderia muito ajudar para compreender tanto o desenvolvimento de nosso passado, no século XX marcado pela falência do "socialismo" de tipo soviético, quanto de nosso presente, em que a sociedade capitalista não parece ser, ao mesmo tempo, vigorosa e portadora de potencialidades benéficas ao incremento das individualidades e do gênero humano. 


\section{Referências}

ALMEIDA, Silvio Luis. O Direito no jovem Lukács. São Paulo: AlphaOmega, 2006.

CHASIN, José. Marx: Estatuto Ontológico e Resolução Metodológica. São Paulo: Boitempo, 2009.

CLAUDIN, Fernando. A crise o movimento comunista. Trad. José Paulo Netto. São Paulo: Expressão Popular, 2013.

HOBSBAWM, Eric. A era dos extremos. Trad. Marcos Santarrita. Rio de Janeiro: Paz e Terra, 1994.

LUKÁCS, György. El Joven Hegel: y los problemas de la sociedad capitalista. Tradução Manuel Sacristan. Mexico, Grijalbo, 1963.

LUKÁCS, György. História e consciência de classe. Trad. Rodnei Nascimento. São Paulo: Martins Fontes, 2003.

LUKÁCS, György. Meu caminho para Marx. Trad. Luiza L. S.

Sakamoto, Marilene G. Pottes e M. Dolores Prades. Revisão técnica de Thereza Calvet de Magalhães. Verinotio: Revista on line de Filosofia e Ciências Humanas, Rio das Ostras: UFF, ano VI, n. 12, 2010.

LUKÁCS, György. Para uma ontologia do ser social II. Tradução por Nélio Schneider. São Paulo: Boitempo, 2013.

LUKÁCS, György. Táctica y ética. Tradução Miguel Vedda. Buenos Aires: El Cielo por Assalto, 2005.

MARTINS, Maurício Vieira. Marx, Spinoza e Darwin, pensadores da imanência. Niterói: Coleção Niepe Marx, 2017.

MARX, Karl. Miséria da filosofia. Trad. José Paulo Netto. São Paulo: Global, 1986b.

MARX, Karl. O capital, Livro I, Tomo I. Trad. Regis Barbosa e Flávio R. Kothe São Paulo: Nova Cultural, 1996.

MARX, Karl. O capital, livro III, tomo I. Trad. Tradução por Regis Barbosa e Flávio R. Kothe São Paulo: Nova Cultural, 1986a. 
MÉSZÁROS, István. Lukács'concept of dialetic. London: Merlin Press, 1972.

MÉSZÁROS, István. Para Além do Capital: Rumo a uma Teoria da Transição. Trad. por Paulo Cezar Castanheda e Sérgio Lessa. São Paulo: Boitempo, 2002.

OLDRINI, Guido. György Lukács e os problemas do marxismo do século 20. Trad. Mariana Andrade. Maceió: Coletivo Veredas, 2017.

SARTORI, Vitor Bartoletti. Direito, ética e generidade na obra madura de György Lukács: acerca das tensões que permeiam o complexo jurídico. Revista Quaestio Iuris, Rio de Janeiro, 2017.

SARTORI, Vitor Bartoletti. Friedrich Engels e a moral frente ao fenecimento do Estado. Direito e Práxis, Rio de Janeiro: UFRJ, v. 7, n. 3, 2016.

SARTORI, Vitor Bartoletti. Lukács e a especificidade da questão da ética: apontamentos sobre a crítica lukacsiana ao Direito e à moral. Revista Direitos Humanos e Democracia, Vitória, UFES, v. 6, 2018 a. SARTORI, Vitor Bartoletti. Lukács e Heidegger: ontologia nos extremos. São Paulo: Intermeios, 2019. (no prelo).

SARTORI, Vitor Bartoletti. Moral, ética e Direito: Lukács e a teoria do Direito. Sapere Aude, Belo Horizonte, PUC MG, 2015.

SARTORI, Vitor Bartoletti. Trabalho, riqueza e natureza humana: Marx e a crítica ao modo de produção capitalista. Sapere Aude: Revista de Filosofia, Belo Horizonte, PUC MG, v. 9, 2018 b.

TERTULIAN. Nicolas. Lukács e seus contemporâneos. Trad. Pedro Campos de Araújo Corgozinho. São Paulo: Perspectiva, 2016.

TERTULIAN. Nicolas. Lukács: Etapas de seu pensamento estético. Trad. Renira Lisboa de Moura Lima. São Paulo: Unesp, 2008. 
Vitor Bartoletti Sartori é professor da Faculdade de Direito e Ciências do Estado da UFMG.

E-mail: vitorbsartori@gmail.com

Endereço profissional: Rua João Pinheiro, n. 100, centro, Belo Horizonte, MG. CEP: 30130-180.

ORCID https://orcid.org/0000-0001-9570-9968 